\title{
DNA Base Sequence Homology in Rhizoctonia solani Kühn V. Genetic Relatedness within AG-6
}

\author{
Shiro Kuninaga* and Ryozo YokosawA* \\ 国永史朗*・横沢菱三*：Rhizoctonia solani における DNA 塩基配列の相同性 \\ $\mathrm{V}$. 菌系融合群第 6 群内における遺伝的類縁性
}

\begin{abstract}
DNA base sequence homology among AG-6 isolates of Rhizoctonia solani was determined by DNA-DNA reassociation kinetics. Five of 10 isolates examined shared high DNA homology ranging from 91.8 to $97.7 \%$. This group was classified as AG-6 homogeneous group I (HG-I). DNA homology among the remaining 5 isolates was 55.4 to $66.2 \%$. They showed only 47.5 to $62.9 \%$ DNA homology with AG-6 HG-I isolates. These isolates were designated $\mathrm{AG}-6$ genotypic variation $(\mathrm{GV})$ isolates. Each of them appeared to have gene structures that differed by nucleotide substitutions. The genetic divergence among AG- 6 isolates was also clearly demonstrated by the electrophoretic patterns of proteins and appearances of the cultures. These results suggest that AG-6 consists of strains that are phylogenetically related but have significant genetic polymorphism. (Received December 23, 1983)
\end{abstract}

Key Words : Rhizoctonia solani (AG-6), DNA homology, genetic relatedness.

\section{Introduction}

Previous studies ${ }^{8-11)}$ in this series of investigations reported that there are cases where all the isolates in a given anastomosis group (AG) of Rhizoctonia solani Kühn were genetically homogeneous. While this was demonstrated in the case of AG-2-1, AG3, AG-5, AG-7 and AG-BI, it was shown that AG-1, AG-2-2 and AG-4 must be considered genetically heterogeneous groups.

AG-6 of $R$. solani is a new group detected in Japan ${ }^{12)}$. This group is widely distributed in non-cultivated soils ${ }^{12)}$. The present study attempts to clarify genetic relationship among isolates in this group on the basis of DNA-DNA reassociation kinetics.

\section{Materials and Methods}

Ten isolates of AG-6 selected to represent morphological types within the group were used. All were isolated from non-cultivated soils at various areas of Hokkaido ${ }^{12}$. The characteristics of these isolates are given in Table 1.

* Department of General Education, Higashi Nippon Gakuen University, Onbetsu, Hokkaido 088-01, Japan 東日本学園大学教養部 
Table 1. Isolates of Rhizoctonia solani used

\begin{tabular}{l|c|l|l}
\hline \hline AG-6 isolate & Source $^{\text {a) }}$ & \multicolumn{1}{|c}{ Geographic origin ${ }^{\text {b) }}$} & Date \\
\hline UBウ-1-A & Soil & Ubaranai, Abashiri-shi & June, 1976 \\
HAM1-1 & Soil & Hamamasumura, Hamamasu-gun & Aug, 1977 \\
NTA3-1 & Soil & Nakataiki, Hiroo-gun & June, 1977 \\
AT2-1 & Soil & Akkeshi, Akkeshi-gun & May, 1977 \\
OHT1-1 & Soil & Ohtakimura, Usu-gun & July, 1977 \\
SO2-1 & Soil & Soya, Wakkanai-shi & Aug, 1977 \\
NKN2-1 & Soil & Nukanai, Nakagawa-gun & June, 1977 \\
KNB2-2 & Soil & Konbu, Isoya-gun & July, 1977 \\
HN1-1 & Soil & Horonuka, Rumoi-gun & Aug, 1977 \\
TSH1-1 & Soil & Teshikaga, Kawakami-gun & May, 1977 \\
\hline
\end{tabular}

a) Non-cultivated soils (Kuninaga \& Yokosawa, 1978) ${ }^{122}$.

b) In Hokkaido prefecture.

Methods for fungal cultivation, the preparation of DNAs, measurement of melting temperature (Tm) of DNAs, shearing of DNAs and the determination of DNA fragment size as well as for calculation of DNA homology values were described in previous papers $^{7, \varepsilon)}$. DNA-DNA reassociation kinetics were observed in $5 \times \mathrm{SSC}$ containing $20 \%$ DMSO at a temperature about $25 \mathrm{C}$ below $\mathrm{Tm}$. Methods for polyacrylamide gel electrophoresis of mycelial soluble proteins were also described previously ${ }^{11}$.

\section{Results}

\section{Thermal denaturation of $\mathrm{DNA}$ of $A G-6$ isolates}

The Tm of DNA from AG-6 isolates was examined as a measure for determining the

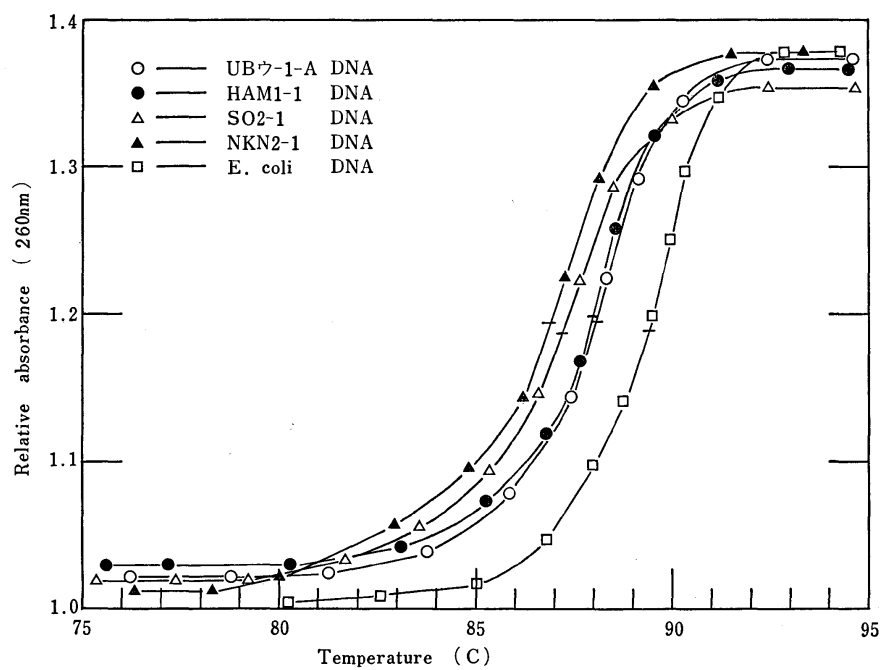

Fig. 1. Thermal denaturation profiles of DNA of AG-6 isolates of Rhizoctonia solani and Escherichia coli in $5 \times \mathrm{SSC}$ containing 20\% DMSO. Bar designates Tm value. 
Table 2. Thermal denaturation and base compositions of DNA of AG-6 isolates of Rhizoctonia solani

\begin{tabular}{l|c|l}
\hline \multicolumn{1}{c|}{ Isolate } & $\begin{array}{c}\text { Tm a) in } 5 \times \mathrm{SSC} \\
+20 \% \text { DMSO }\end{array}$ & $\begin{array}{c}\text { Base composition } \mathbf{b}) \\
(\mathrm{GC} \text { mole } \%)\end{array}$ \\
\hline UBウ-1-A & 87.9 & 46.1 \\
HAM1-1 & 87.8 & $45.9(41.4)^{\mathrm{c})}$ \\
NTA3-1 & 87.8 & 45.9 \\
AT2-1 & 87.6 & $45.4(42.2)^{\mathrm{c})}$ \\
OHT1-1 & 87.8 & 45.9 \\
SO2-1 & 87.1 & $44.2(41.8)^{\mathrm{c})}$ \\
NKN2-1 & 86.7 & 43.2 \\
KNB2-2 & 87.1 & 44.2 \\
HN1-1 & 86.8 & 43.5 \\
TSH1-1 & 86.9 & 43.7 \\
\hline
\end{tabular}

a) The temperature corresponding to the midpoint of absorbance rise (Marmur \& Doty, 1962) ${ }^{14)}$.

b) E. coli DNA (GC mole $\%=50$ ) was used as a standard. The base composition of $R$. solani DNA was calculated on a equation modified from Marmur \& Doty (1968) ${ }^{14)}$ : GC mole $\%=50+(\mathrm{Tm}$ R. solani DNA-Tm E. coli DNA/0.41).

c) Base composition determined by chemical analysis (Kuninaga \& Yokosawa, 1980) $)^{7}$.

Table 3. DNA homology among isolates of Rhizoctonia solani AG-6

\begin{tabular}{|c|c|c|c|c|c|c|c|c|c|c|}
\hline & \multicolumn{5}{|c|}{ AG-6 homogeneous group I isolates } & \multicolumn{5}{|c|}{ AG-6 genotypic variation isolates } \\
\hline & $\mathrm{UB}$ ウ-1-A & HAM1-1 & NTA3-1 & AT2-1 & OHT $1-1$ & $\mathrm{SO} 2-1$ & NKN 2-1 & KNB 2-2 & HN1-1 & TSH1-1 \\
\hline \multirow[t]{10}{*}{$\mathrm{UB}$ ウ $-1-\mathrm{A}$} & $100^{\text {a) }}$ & $93.3^{\mathrm{b})}$ & 91.8 & 95.4 & 92.4 & 53.9 & 58.7 & 49.3 & 48.3 & 49.3 \\
\hline & HAM1-1 & 100 & 93.8 & 92.0 & 97.7 & 62.3 & 47.5 & 55.0 & 55.2 & 53.3 \\
\hline & & NTA3-1 & 100 & 95.8 & -.c) & 58.2 & 49.4 & 55.1 & 61.8 & 一 \\
\hline & & & AT2-1 & 100 & 一 & 57.4 & 56.0 & 60.8 & 51.4 & 一 \\
\hline & & & & OHT 1-1 & 100 & 60.8 & 62.4 & 53.9 & 62.9 & 一 \\
\hline & & & & , & $\mathrm{SO}_{2-1}$ & 100 & 55.4 & 57.3 & 56.3 & 58.7 \\
\hline & & & & & & NKN2-1 & 100 & 66.2 & 61.9 & 60.4 \\
\hline & & & & & & & KNB 2-2 & 100 & 63.4 & 62.4 \\
\hline & & & & & & & & HN1-1 & 100 & 59.4 \\
\hline & & & & & & & & & TSH1- & 100 \\
\hline
\end{tabular}

a) Expected homology value.

b) Average of two or three determinations. All reactions of DNA-DNA reassociation kinetics were carried out in $5 \times \mathrm{SSC}$ containing $20 \% \mathrm{DMSO}$ at $61 \mathrm{C}$.

c) Not determined. 
optimum temperature for DNA-DNA reassociation studies. Thermal denaturation was observed in $5 \times \mathrm{SSC}$ containing $20 \%$ DMSO. Fig. 1 shows the thermal denaturation profiles of DNAs from representative isolates. Degrees of hyperchromicity of DNAs from AG-6 isolates ranged from 33.1 to $39.8 \%$. The Tm values and base compositions of DNAs are presented in Table 2. DNA base compositions of AG-6 isolates were distributed rather widely from 43.2 to 46.1 mole $\%$.

\section{DNA homology among AG-6 isolates}

As shown in Table 3, the various DNA homology values were obtained from observations of 10 isolates in AG-6. High DNA homology values, 91.8 to $97.7 \%$, were observed among 5 isolates (UBウ-1-A, HAM1-1, NTA3-1, AT2-1 and OHT1-1). These isolates were classified as AG-6 homogeneous group I (HG-I). DNA homology values among the remaining 5 isolates (SO2-1, NKN2-1, KNB2-2, HN1-1 and TSH1-1) were 55.4 to 66.2
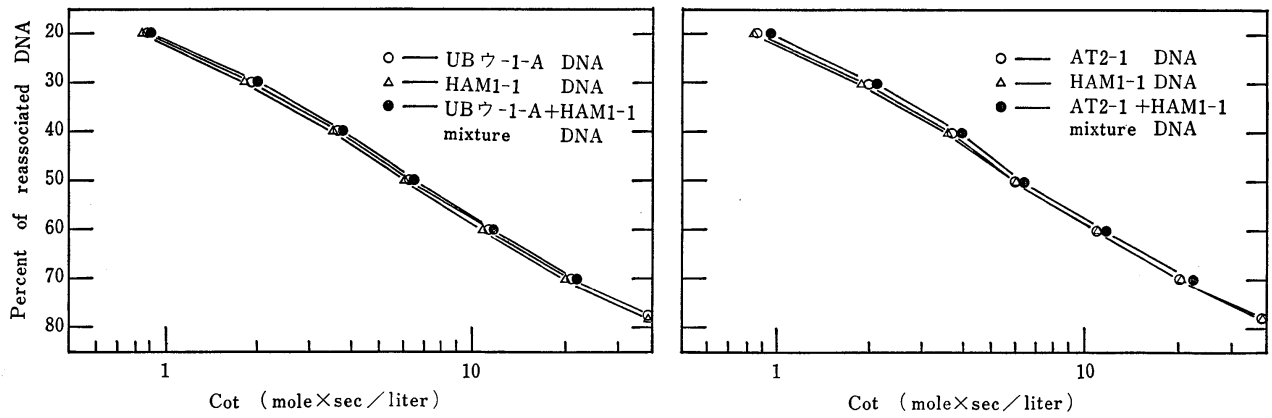

Fig. 2. Reassociation kinetics of the mixture of DNA from isolates of Rhizoctonia solani AG-6. All reactions were carried out in $5 \times$ SSC containing $20 \%$ DMSO at $61 \mathrm{C}$.
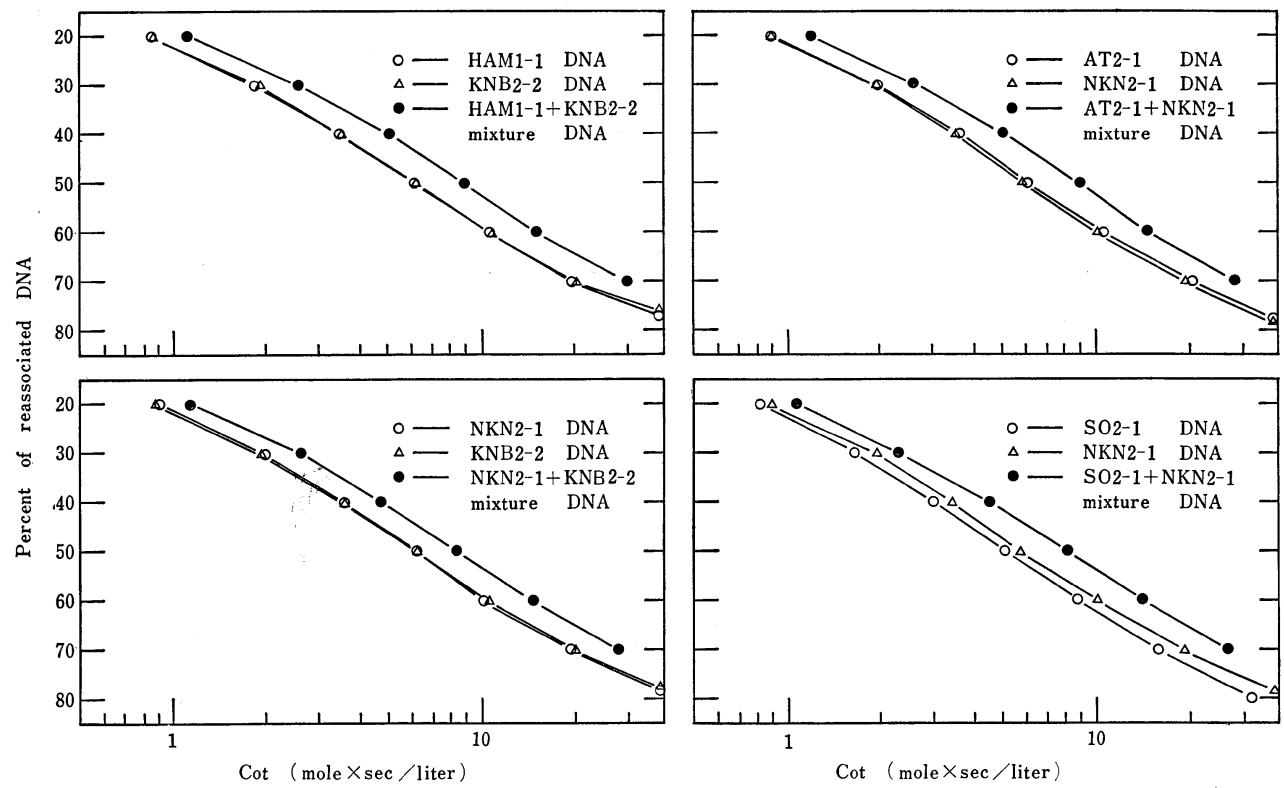

Fig. 3. Reassociation kinetics of the mixture of DNA from isolates of Rhizoctonia solani AG-6. All reactions were carried out in $5 \times \mathrm{SSC}$ containing $20 \% \mathrm{DMSO}$ at $61 \mathrm{C}$. 
9.. These were designated as AG-6 genotypic variation (GV) isolates and showed 47.5 to $62.9 \%$ homology with the isolates in $\mathrm{AG}-6 \mathrm{HG}-\mathrm{I}$. Profiles of DNA reassociation kinetics among representative isolates in $\mathrm{AG}-6$ are shown in Fig. 2 and 3.

\section{Protein similarity among $A G-6$ isolates}

As shown in Fig. 4, all the AG-6 isolates showed a common protein band intensely stained at Ef 0.3. There was also a marked similarity of protein bands at other Ef
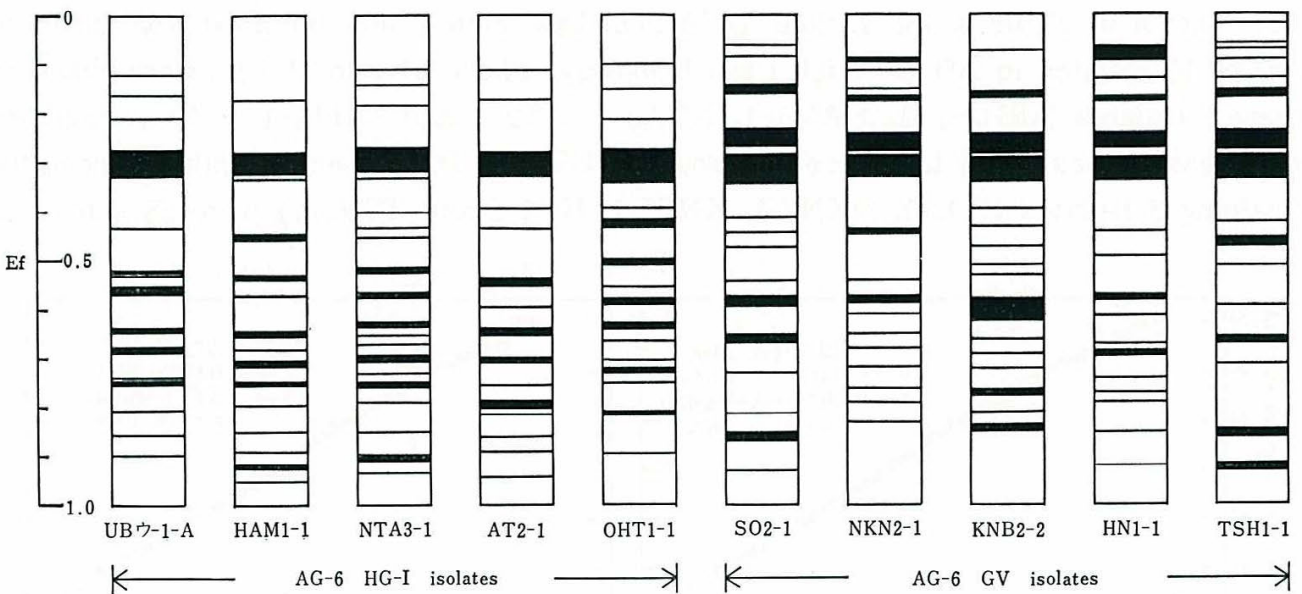

AG-6 HG-I isolates

K

AG-6 GV isolates

TSH1-1

Fig. 4. Electrophoretic profiles of mycelial proteins from AG-6 isolates of Rhizoctonia solani.

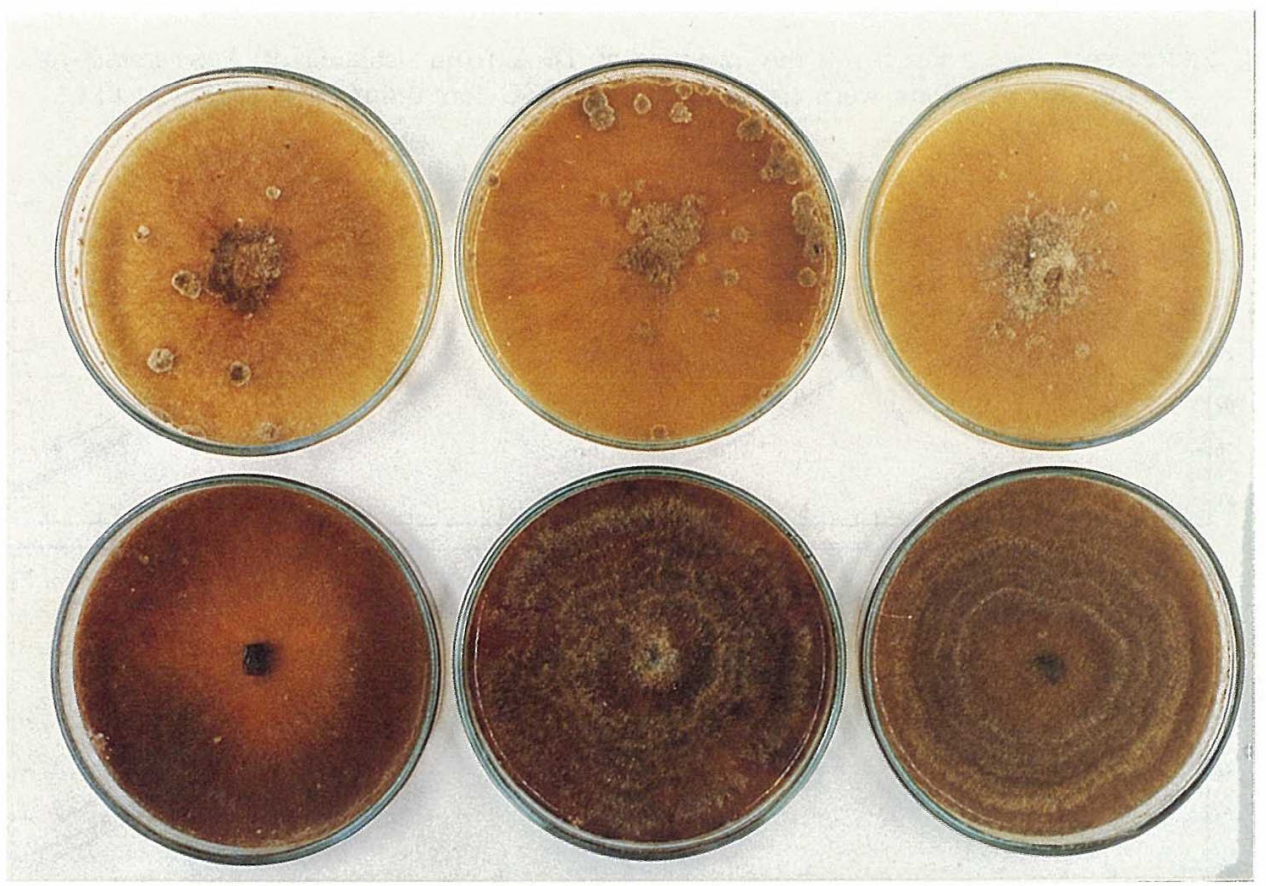

Fig. 5. Cultural appearance of AG-6 isolates of Rhizoctonia solani grown on potato dextrose agar for 14 days at $28 \mathrm{C}$.

AG-6 HG-I isolates-top row (left to right): OHT1-1, UBウ-1-A and HAM1-1. AG-6 GV isolates-bottom row (left to right): NKN2-1, TSH1-1 and HN1-1. 
values among isolates in AG-6 HG-I. There were definite differences in banding patterns between AG-6 HG-I and AG-6 GV isolates. Also, in contrast to protein patterns of isolates in AG-6 HG-I, there was strong protein polymorphism among AG-6 GV isolates.

\section{Cultural appearance of AG-6 isolates}

As shown in Fig. 5, AG-6 HG-I and AG-6 GV were easily distinguished from each other in terms by colony characteristics on potato dextrose agar (PDA) after 14 days. AG-6 HG-I isolates (OHT1-1, UBウ-1-A and HAM1-1) had similar characteristics, as follows: abundant sclerotia, uniform in size, 1.0 to $1.5 \mathrm{~mm}$ diam., often aggregated into compounded sclerotia, mycelioid or wooly surface and change of colour to yellowishbrown in PDA. In contrast, AG-6 GV isolates (NKN2-1, TSH1-1 and HN1-1) showed the following appearances: few or abundant aerial hyphae; concentric zonation in some isolates: generally few or no sclerotia; change of colour to dark brown in PDA.

\section{Discussion}

These studies suggest that AG-6 contains isolates that are genetically homogeneous (here classified as AG-6 HG-I). It also contains isolates having lower DNA homology with each other as well as with the isolates in AG-6 HG-I. The latter heterogeneous isolates were designated as AG-6 genotypic variation (GV) isolates. However, the possibility cannot be excluded that further studies, dealing with large numbers of isolates outside AG-6 HG-I, may detect some forming homogeneous groups different from AG-6 HG-I.

DNA homology between AG-6 HG-I and AG-6 GV isolates ranged from 47.5 to 62.9 $\%$, whereas, that within AG-6 GV was from 55.4 to $66.2 \%$. These results suggest that AG-6 is a genetically polymorphic group composed of strains with partial phylogenetical relatedness.

The present experiments suggest that each of $\mathrm{AG}-6 \mathrm{GV}$ isolates examined possesses a different gene structure arising from particular nucleotide substitutions ${ }^{6,13)}$ or DNA rearrangements ${ }^{2,5)}$ involving about $45 \%$ of the entire molecule of DNAs. This is the unique feature of AG-6, not observed in other AGs of $R$. solani. This suggests that genetic polymorphism in AG-6 has increased the ability for survival of this widely distributed group ${ }^{12)}$.

Previous studies ${ }^{11}$ showed that the relationship among AG-4 isolates as determined on the basis of DNA homology agrees well with that seen in electrophoretic pattern of proteins. In the present study, homologous electrophoretic pattern was presented in AG-6 HG-I. In contrast, polymorphic protein patterns were observed in AG-6 GV isolates that are genetically divergent. These results may be expected from the fact that the primary structure of proteins of organisms is defined by the nucleotide sequences of their DNAs. Our experiments suggest that electrophoretic patterns of total soluble proteins (enzymes) from mycelia may be a useful measure of the relatedness of isolates in AGs of $R$. solani.

In the present study, we also found a relatively wide range of DNA base compositions (GC contents) which may be explained on the basis of the great total variation of 
isolates in $\mathrm{AG}-6$. On the average, $\mathrm{AG}-6 \mathrm{GV}$ isolates showed slightly lower $\mathrm{GC}$ contents than isolates in AG-6 HG-I. The observation of DNA homology values further suggests that AG-6 GV may be a variant group in AG-6 HG-I. If so, the diversification is accompanied by a progressive decrease in GC content.

Storck and Alexopoulos ${ }^{15}$ ) suggested that the evolution of fungi is usually accompanied by a progressive increase of GC content. Conversely, Freese ${ }^{4)}$ and Sueoka ${ }^{16}$ concluded from their mathematical models of DNA base changes by mutation that there is nothing justifying the assumption of unidirectional increase in GC contents during the process of diversification. A final appraisal of the phylogenetical significance of DNA base compositions in $R$. solani may require an accumulation of further information about DNA repetitive sequences ${ }^{1,3,17)}$ and DNA rearrangement ${ }^{2,5)}$ of fungal genomes.

The authors are grateful to Dr. A. Ogoshi, Hokkaido University, and Dr. R. Baker, Department of Botany and Plant Pathology, Colorado State University, for critical reading of this manuscript.

\section{Literature cited}

1. Britten, R. J. and Kohne, D.E. (1968). Science $161: 529-540$.

2. Cullum, J. and Saedler, H. (1981). In Molecular and Cellular Aspects of Microbial Evolution (Carlile, M. J., Collins, J.F. and Moseley, B.E.B. eds.) Cambridge University Press, London and New York. pp. 131-150.

3. Dutta, S. K. (1974). Nucl. Acids Res. $1: 1411-1419$.

4. Freese, E. (1962). J. Theoret. Biol. 3: 82-101.

5. Gafner, J. and Philippsen, P. (1980). Nature $286: 414-418$.

6. Kimura, M. (1981). Proc. Natl. Acad. Sci. U.S.A. $78: 454-458$.

7. Kuainaga, S. and Yokosawa, R. (1980). Ann. Phytopath. Soc. Japan $46: 150-158$.

8. Kuninaga, S. and Yokosawa, R. (1982). Ibid. 48:659-667.

9. Kuninaga, S. and Yokosawa, R. (1982). Ibid. $48: 668-673$.

10. Kuninaga, S. and Yokosawa, R. (1983). Ibid. $49: 647-652$.

11. Kuninaga, S. and Yokosawa, R. (1984). Ibid. $50: 322-330$.

12. Kuninaga, S.. Yokosawa, R. and Ogoshi, A. (1978). Ibid. $44: 591-598$ (In Japanese).

13. Laird, C. D., McConaughy, B. L. and McCarthy, B. J. (1969). Nature $224: 149-154$.

14. Marmur, J. and Doty, P. (1962). J. Mol. Biol. 5 : 109-118.

15. Storck, R. and Alexopoulos, C. J. (1970). Bacteriol. Rev. 34:126-154.

16. Sueoka, N. (1962). Proc. Natl. Acad. Sci. U.S.A. 48:582-592.

17. Szécsi, À. (1981). Exp. Mycol. $5:$ 323-329.

\section{和 文 摘 要}

\section{Rhizoctonia solani における DNA 塩基配列の相同性 $\mathrm{V}$ ．菌系融合群第 6 群内に打ける遺伝的類縁性}

\section{国永史朗・横沢菱三}

Rhizoctonia solani の菌系融合群第 6 群（AG-6）内に扝䐃菌株間の遗伝的類縁性を検討するため, DNADNA 再会合反応速度解析に基づき, DNA 塩基配列の相同性を比較した。その結果, AG-6 は遺伝的化均一 な菌株の一群と様々な遺伝的分化を示す菌株とから成るととがわかった。前者を AG-6 homogeneous group I (HG-I), 後者を AG-6 genotypic variation (GV) 菌株とした。AG-6 HG-I 菌株間相互の DNA 相同 性は91.8\% 97.7\%, AG-6 GV 菌株間相互では55.4\%〜 66.2\%であった。また AG-6 HG-I 菌株と AG-6 GV 菌株間では $47.5 \%$ 62.9\%であった。AG-6 菌株間の遺伝的な多様性は菌体可溶性蛋白電気泳動パター ンおよび培養型比較結果からあよく示された。以上の結果は, AG-6 は遺伝的多型を示す群であり, 系統的に は互いに近縁な菌株汃ら成るととを示唆する。 